\title{
DEFINING THE TERM "INTELLIGENCE" - INSIGHT INTO EXISTING INTELLIGENCE KNOWLEDGE
}

\section{DEFINIRANJE POJMA „OBAVJEŠTAJNO“ - UVID U POSTOJEĆE OBAVJEŠTAJNO ZNANJE}

\author{
Tomislav Dokman \\ Faculty of Humanities and Social Sciences, University of Zagreb, Zagreb, Croatia \\ Filozofski fakultet, Sveučilište u Zagrebu, Zagreb, Hrvatska
}

\section{Abstract}

For more than half a century of Intelligence Studies, this field has been characterized by the problem of lack of uniform definition of the term intelligence, a contentious place in the corpus of existing knowledge. The determinant of this is the existence of different types of intelligence, that is, the term is related to the intelligence product or information, the process/cycle in which information is collected, processed, analyzed and disseminated, and to the intelligence producing organization. Furthermore, it is a broad concept that initially developed and presented itself throughout history as exclusive state property, only later to become an equally represented term in other fields, more specifically business, science, sports, etc. Defining the term "intelligence" is important not only for the sake of development of intelligence theory and scientific discipline, but also because of the practical part of "intelligence" which is an essential feature of every state as it provides support for state decision-making process and defining policies in the national security spectrum. The paper analyzes 35 scientific, expert and institutional definitions of the term intelligence using quantitative and qualitative content analysis. Qualitative content analysis identified 15 key elements. The quantitative analysis found that the most represented element was "information", followed by "end user/decision maker", followed by
Sažetak

Više od pola stoljeća postojanja obavještajnih studija (Intelligence studies) ovo područje karakterizira problem jednoznačnog definiranja pojma obavještajnog koji predstavlja sporno mjesto u korpusu postojećeg znanja. Determinanta toga je postojanje različitih tipova obavještajnog, odnosno pojam se dovodi u vezu s produktom obavještajnog djelovanja ili informacijom, procesom/ciklusom u kojem se prikupljaju, obrađuju, analiziraju i diseminiraju informacije te organizacijom koja proizvodi obavještajno znanje. Nadalje, riječ je o širokom pojmu koji se kroz povijest inicijalno razvijao i predstavljao kao isključivo državno svojstvo, da bi kasnije postao jednako zastupljen pojam $u$ drugim djelatnostima, konkretnije poslovanju, znanosti, sportu i sl. Definiranje pojma "obavještajno" bitno je ne samo radi razvoja obavještajne teorije i znanstvene discipline nego i zbog praktičnog dijela "obavještajnog“ koji je esencijalno obilježje svake države u vidu potpore donošenju državničkih odluka ali i definiranja politika iz spektra nacionalne sigurnosti. U radu je korištenjem kvantitativne i kvalitativne analize sadržaja analizirano 35 znanstvenih, stručnih te institucijskih definicija pojma obavještajnog. Kvalitativnom sadržajnom analizom identificirano je 15 ključnih elemenata. Kvantitativnom analizom utvrđeno je da je najzastupljeniji element „informacija“, potom „krajnji korisnik/donositelj odluka“, zatim slijede 
"actionable character", "foreign countries" and "knowledge". Based on the elements extracted, a new definition is presented. Intelligence is characterized by actionable knowledge of foreign/other countries that is disseminated towards end users, i.e. decision makers, in the form of information.

\section{Introductory thoughts: The controversy of the term "intelligence"}

For more than half a century of Intelligence Studies' existence, this area has been characterized by the problem of the lack of a uniform definition of the term intelligence, which is a contentious place in the field of existing knowledge. Although the area is characterized by a significant body of scientific and professional pages and sites as well as by a large number of scientists and experts, the question arises as to why the academic and professional communities have not yet unambiguously defined this term. Does this stem from the fact that the term is differently defined in different countries and that there are significant traditional differences between the intelligence systems of individual countries, or is it, irrespective of tradition, a disagreement between practitioners and theorists? Could something else be in question? All of these questions are justifiably imposed on many who are involved with intelligence in various ways. On the other hand, it is also possible to question the feasibility of an unambiguous definition, and, ultimately, the very need to define the term.

Despite the occasional search for a uniform definition of intelligence, the expertscientific public has not yet unanimously accepted any of the presented definitions. The core issue is the approach itself, which is often characterized by the subjectivity of the author, unsystematic study of the corpus of intelligence and absence of scientific methodology. In addition, each individual contribution to the presentation of a new definition arose as a result of a rare complement to existing definitions, that is, almost without any correlation with other definitions /1/. The problem is also the complexity of the term, as "akcijabilni karakter“, „strane države“ i "znanje“. Na temelju izlučenih elemenata predstavljena je nova definicija. Obavještajno karakterizira akcijabilno znanje o stranim/drugim državama koje se u obliku informacije diseminira prema krajnjim korisnicima, odnosno donositeljima odluka.

pointed out by Walter Laquer, emphasizing that the term has multiple meanings $\mathbf{2} /$, while Bimfort is among those who think that defining intelligence is a difficult task because every expert takes a different view of the term and most often defines it in accordance with his own experience and from the perspective of his narrow specialist field of activity $/ 3 /$. In this regard, Bimfort makes it clear that the term will be unequally defined by different actors in the intelligence field: military definition will differ from the civilian one; also, individuals involved in collecting data will have different approach from those involved in the production of the final intelligence product /3/. For example, Kahn claims that "no definition works" /4/. Warner /5/ says that intelligence, by definition, "resists" academic study because intelligence systems rarely allow empirical research based on insights into official documents of intelligence institutions to be conducted.

In the search for a uniform definition, it is necessary to synthesize and analyze the existing knowledge in the field of Intelligence Studies or the existing definitions of the term intelligence. In doing so, Marrin /6/ emphasizes that a consensus of the academic and professional public may not even be needed to define the term intelligence, as other fields have not unanimously adopted a single definition of either term or phenomenon. For example, Bilandžić and Lucić /7/ has argued that neither the scientific nor the professional public has yet reached a consensus on defining the concept of terrorism, which is also a contentious place in the overall knowledge of terrorism and definitely influences the definition of applied counter-terrorism policies and strategies. However, in terms of defining intelligence, the reason for not having a generic definition is expected and obvious for Bimfort $/ \mathbf{3} /$ because it 
is difficult to formulate a definition for such a widely applicable term; however, the aforementioned does not imply that our efforts cannot result in success. For Bimfort, "finding a short definition of a comprehensive term is like making a microscopic portrait of a continent" /3/. Nevertheless, in his paper "Wanted: A Definition of Intelligence", Michael Warner, prominent author in the field of Intelligence Studies, clearly emphasizes why it is important to create a uniform definition of the term intelligence. Warner $\mathbf{1}$ / says that without a clear assumption of what the term intelligence entails, we can neither develop intelligence theory, nor build an understanding of the term itself. It is precisely for the development of a theory that a general knowledge of a problem, in this case the concept of intelligence and the activity itself, is essential, whereby theories are understood according to the general principles, causes and consequences, that is, as a set of general knowledge aimed at explaining empirical observations /8/. Because of that, it is essential to search for a functional definition of the term intelligence, as resolutely pointed out by Warner. In addition to the general misunderstanding of the term, Alan Breakspear /9/ believes that attempts to standardize definitions can lead to certain negativities, that is, "narrowing intelligence practices, reducing intuition and procedural actions". At the same time, Breakspear believes that a clear definition will still have positive effects and will lead to more explicit and "clearer communication among intelligence actors" and a better understanding of the term by "the academic community, the media and the general public" /9/. In any case, it is a complex concept which, if not clearly defined, opens the discussion on how can the intelligence community know exactly what it is doing /10/. A step further in the critical approach to defining intelligence was made by Thomas Troy /11/, who emphasized that it is crucial to understand and define the notion in order for state systems, that is, intelligence institutions, to not be confronted with inadequate priorities and tasks. On the other hand, members of the scientific community, as actors in Intelligence Studies, are aware of the need to uniformly define the term, but also of the difficulties of this endeavor, since the term has a psychological character as well, as it deals with the ability to think and learn, and is associated with support to decision making process /9/. In addition, Breakspear /9/ says that the term intelligence is also characterized by the ability to anticipate changes in the external environment and to support management structures in order to achieve positive change, that is, the benefits, and at the same time to minimize and avoid adverse or negative effects. The author emphasizes that the term is equally related to state systems and corporations, nongovernmental organizations, professional and sports associations, etc. For Warner $/ \mathbf{1} /$, on the contrary, the key determinant of the notion of intelligence is secrecy, emphasizing that secrecy cannot be separated from intelligence. However, for Breakspear /9/ secrecy is not a constituent feature of the notion of intelligence, although intelligence has a significant impact on policy making /12/, as "knowledge is the best tool for good policy" /7/. Therefore, the aim of this paper is to conduct a more systematic empirical analysis of the existing definitions of intelligence, and to present an operational definition based on qualitative and quantitative content analysis contributing in that way to further understanding of the concept of intelligence. Thus, in addition to theoretical input, the paper also contributes to the advancement of practical knowledge that is crucial from the point of view of intelligence in the context of state activity, but also in all other areas in which intelligence is important.

\section{Different views on defining the term intelligence}

Historically, the emergence of intelligence goes back to the era of the great Chinese military strategist and thinker Sun Tzu, who, almost 2,500 years ago, spoke of the use of intelligence activities and tactics to gain strategic advantage, as he vividly portrayed in his epochal work The Art of Warm/13/. The term intelligence as we know it today, but also specific intelligence activity, is also recorded in the Bible. The Book of Numbers in chapter 13 undoubtedly describes intelligence and intelligence collecting, ultimately, knowledge: 
"The LORD said to Moses: Send men, one man from each ancestral tribe, to survey the land of Canaan, which I give to the Israelites" /14/. The later view of intelligence and intelligence activities replicates early biblical accounts of intelligence activity so in this context we point to Constantine FitzGibbon, who emphasized in the late 1970s that the term intelligence implies "knowledge of the adversary" /11/, and that knowledge gives us some advantage over the opponent or opposing actor. In addition, the term has been linked to spying throughout history /11/. However, since the inception of Intelligence Studies, a whole host of scientists and experts have been studying the concept of intelligence $/ \mathbf{1 5} /, / 3 /, / \mathbf{1 1} /, / \mathbf{1 6} /, / \mathbf{1 7} /, / \mathbf{1 8} /, / 1 /, / 19 /$, $/ \mathbf{1 0} /, / \mathbf{2 0} /, / \mathbf{2 1} /, / \mathbf{9} /$, as well as deliberately contemplating determination of the intelligence theory which is still missing from the Intelligence Studies /15/, /12/, /22/, /23/, /24/, $/ 25 /$. Still, in addition to numerous definitions of intelligence, the corpus of intelligence also shows a significant dispersion in terms of understanding of the term itself, which implies knowledge and information, a particular product and the process whereby intelligence data is collected, processed, evaluated and disseminated. Thus, in this context, we can talk about both of the cycle and the organization that collects, analyzes and disseminates information.

The Oxford Dictionary /26/ defines intelligence as the ability to acquire skills and knowledge, the ability to apply knowledge, and also as information or news. The Cambridge Dictionary /27/, on the other hand, describes the term as the ability to "learn, understand, and reason." First, on the basis of dictionary definitions alone, it can be concluded that when we talk of acquisition of skills and knowledge, we can say it is a specific proceeding or process within which information is collected that enhances specific knowledge. Second, here we come across information or news that undoubtedly corresponds to a so-called intelligence product that is disseminated to end users. And third, the application of knowledge is best described by an action element that enables and facilitates end-users' decisionmaking. It is decision making that is the "crucial force" and the determinant of "growth, domination and survival" in terms of national security /19/. Decision-making, whether it comes from the spectrum of government affairs related to foreign, internal and security policy or from the spectrum of corporate decisionmaking in the context of a market economy and as part of a personalized move to make individual decisions, is determined by the type and quality of knowledge. It should be noted that the Second Hoover Commission in the United States in 1955, containing Task Force on Intelligence Activities, considered and studied the possibility of launching a sui generis definition of the term intelligence (CIA) and came to the conclusion that the term would be adequately defined if it involved the timely detection of threats and subsequent action to prevent the potential consequences of a sudden attack $/ \mathbf{2 8} /$. Since the emergence of Intelligence Studies, the term intelligence has also been defined in detail by Sherman Kent, who emphasized the following:

"(...) intelligence is a simple and selfevident thing. As an activity it is the pursuit of a certain kind of knowledge; as a phenomenon it is the resultant knowledge ... And strategic intelligence, we might call the knowledge upon which our nation's foreign relations, in war and peace, must rest $/ \mathbf{1 5} /$.

Kent /15/ splits the term intelligence three ways: a) unique knowledge; b) a knowledge-collecting organization; and c) an activity, that is, a process. The process or cycle traditionally implies request planning, data collection, processing, analysis and dissemination of the finished product. For example, Miroslav Tuđman /19/ by this term means the final product which results from the intelligence process, i.e. the collection, processing, analysis, linking, evaluation and interpretation of available knowledge pertaining to a particular request. Also, Bilandžić and Mikulić /29/ consider that intelligence is best characterized by information and activity and organization at the same time, while the ultimate intelligence product is characterized by its actionable character and serves as a support to decision makers. 
Javorović and Bilandžić /21/ also point to an actionable character, stating that:

(...) it is essential that this final intelligence product, which enables the grasping and understanding of a particular problem, also contains an action element, namely, that it is the basis for the authorized participants to make decisions or take certain actions. (...) the final intelligence (reporting) analyses which are not the basis for action represent merely the processed information on a very high level.

Conversely, for Roy Godson /30/, this concept is most accurately defined by four elements: a) data collection; b) analytical processing; c) counterintelligence and d) covert operations. In other words, in his approach to the characteristics of the term, Godson introduces counterintelligence and covert operations that are considered intelligence activities; however, what they have in common is the data collection manifested in counterintelligence through detecting and counteracting intelligence activity of foreign intelligence systems and protecting the constitutional order and functioning of state institutions as well as prevention of unauthorized and irregular access to secret or classified information. In the context of covert operations in the data collection segment, the objective is to achieve a certain advantage in accordance with the specific requirement of the covert operation. On the other hand, in their book Intelligence for Economic Development: An Inquiry into the Role of the Knowledge Industry, Dedijer and Jequier $/ \mathbf{3 1}$ / referred to the semantic complexity of the term intelligence, thus emphasizing that there are certain ambiguities with the term intelligence itself, and asked: "What is implied by 'intelligence', intelligence policy or intelligence activity? How is the concept related to knowledge, information, data and knowledge production or information systems?". Talking about ambiguities and different understandings of the term, Dedijer and Jequier point out that the term does not have the same meaning in the United Kingdom, where it has a broader meaning than in the United States, while in France it is understood as human intelligence rather than a government agency conducting intelligence activities. Scott and Jackson /32/ say that the word renseignement, meaning research, is more commonly used in France. The term intelligence in the United States is characterized by a final product, that is, a product of intelligence work that was created on the basis of collection, processing and analysis; it is used in reporting to decision makers and is characterized by its action potential /33/. One of the definitions of the term intelligence, arguably most consistent with Davies' claims, is the US system's, precisely US Department of Defense's definition, which defines it as "a product of collecting, evaluating, analyzing, integrating and interpreting all available information relating to one or more aspects of others countries or areas of operations which is currently or potentially useful for future planning" /34/. The American model rests on the collection of unprocessed, so-called raw intelligence, but still, it is the analytical processing that is a fundamental determinant of the final product, which means that the intelligence product is actually a product of analytical processing /33/. Unlike the US, where intelligence is marked by the end product resulting from analytical processing, the British model of understanding the concept of intelligence is related to raw intelligence disseminated to target users, most often to decision makers who are then responsible for analyzing and evaluating the data collected as well as for making the best decision possible based on those data $/ 33 /$.

\section{A short review of earlier research}

The initial contribution to the deconstruction of the problem of uniformly defining the concept of intelligence was presented by Thomas F. Troy in 1991/11/ in his critical work The Correct Definition of Intelligence. Troy presented a descriptive overview of definitions of his choice of the term intelligence, without entering into a concrete and in-depth substantive analysis of the constituent elements of the observed definitions, or presenting a new definition of the term based on existing knowledge in the field of Intelligence Studies. The author critically referred to selected definitions and presented four features of the 
concept of intelligence, that is, intelligence activities. He emphasizes that intelligence is: 1 ) a subjective term; 2 ) activity directed towards others and not ourselves; 3) an activity that must be focused on collecting intelligence on an opponent or enemy, and 4) a discipline or instrument of conflict that will be an important element of conflict in the future /11/. The continuous lack of a uniform definition of intelligence and also of an adequate intelligence theory was the basis for introduction of a new definition by Michael Warner, who considered the definition a key precondition for the development of intelligence theory. In 2002, Warner /1/ analyzed seventeen different definitions of the term intelligence in his work Wanted: A Definition of Intelligence, and pointed out five constituent elements of the analyzed definitions, according to which intelligence consists of: (1) secret sources and covert methods; (2) civil servants conducting intelligence activities for state purposes; (3) foreign targets such as states, groups, entities and corporations; (4) production and dissemination of information; and (5) influence on foreign entities. For Warner, the term intelligence is "more than information" / $\mathbf{1}$, emphasizing that this feature of the term is too basic, especially for intelligence personnel and less for intelligence users. He believes that the key element of the term is secrecy. Moreover, he claims that not all information is an intelligence product and stresses that "news articles or atlases" do not conceal intelligence products. However, we do not believe that any classified information is an intelligence product. Contrary to Warner's assertions, it is important to emphasize that information, whether coming from the public spectrum or a secret source, and before it becomes an intelligence product at all, must meet the criteria of timeliness, accuracy and actionability. In the proposed definition, Warner argues that "intelligence is a covert state activity aimed at understanding or influencing foreign entities" /1/. The next search for a uniform definition is co-authored by Wheaton and Beerbower in 2006. Their research was presented in their paper Towards a New Definition of Intelligence in which they compared the definitions of experts, legislative institutions, intelligence institutions and the law and order enforcement as well as definitions in the field of business intelligence. For Wheaton and Beerbower, the constituent elements of the term are: (1) process; (2) information; (3) focus on foreign/external entities and (4) the environment in which the organization operates $/ \mathbf{1 0} /$. The last recorded intention to uniformly define the term intelligence was noted in 2013 in Alan Breakspear's A New Definition of Intelligence, in which the author identified the basic components of some of the definitions of the term intelligence, endeavoring to identify key factors that for him would be the foundation for future definition /9/. Without using the methodological framework, the author claims that the term intelligence is correlated with the ability to think, learn and use what was learned, which in turn he links to certain definitions in psychology. At the same time he denies secrecy as a constituent element of the term, stating that intelligence is not solely a state but also nonstate activity. As part of this research, Breakspear has proposed a new definition of intelligence, whereby the term denotes:

(...) corporate capability to change in time to do something about it. The capability involves foresight and insight, and is intended to identify impending change that may be positive, presenting an opportunity, or negative, presenting a threat (...) $/ 9 /$.

Nevertheless, none of the recorded attempts to analyze the existing intelligence knowledge has resulted in a uniform definition that would be a consensual solution within the scientific and professional public. Moreover, the presented papers lacked a more concrete scientific analysis of the existing knowledge, i.e. available definitions. A more concrete survey of intelligence knowledge, using Q-methodology to objectively study subjective definitions, was applied by Milton Diaz /35/ in Forming a Definitional Framework for Intelligence, in 2011. Diaz attempted to extract bias by including three groups of respondents in the study; more specifically theoreticians, experts and end users. A total of 66 respondents were subjected to a set of claims, definitions, and statements 
from the field of Intelligence Studies, and their reflections, in the form of positive and negative arguments, were extracted by the author into a database of so-called logical elements used to create one lexical and one theoretical definition. The core of the theoretical definition consists of five elements (process, knowledge, decisionmaking, actor and national security), and the lexical definitions have three elements (process, knowledge and decision-making). Although this is the first more systematic and scientific study of existing knowledge, the work and the proposed definitions have achieved neither positive nor negative academic or expert reviews.

\section{Methodology - construction of the intelligence definition database}

In order to gain a more specific insight into the segment of registered or existing intelligence knowledge, the emphasis was put on constructing a database of definitions of the term intelligence with 35 definitions $(\mathrm{N}=35)$. The database consists of scientific and academic definitions, definitions of different nongovernmental organizations, as well as of the state systems such as different ministries, etc. The database is being filled through examination of scientific and professional literature in the field of Intelligence Studies. The absence of a uniform definition of intelligence is not a problem for Intelligence Studies solely, but also other fields of the social sciences are searching for a uniform definition. A very interesting and obvious example is one in the field of terrorism studies, where there have been multiple attempts and models to come up with a unique definition, and certainly the most famous is that by Alex Schmidt and Albert Jongman $/ 36 /$.

Their pioneer $1988 / 36 /$ attempt included 109 definitions of terrorism, whereby a quantitative analysis of the words forming the definitions was conducted with the collected definitions. The authors identified the constituent elements of each individual definition, resulting in 22 extracted elements.

\footnotetext{
${ }^{7}$ Given that $10 \%$ of the 35 definitions makes a representation of $3.5 \%$, those that appear in at least four definitions are taken as relevant elements.
}

Croatian authors Bilandžić and Lucić /7/ also created a database of definitions of terrorism, where they included the largest number of definitions $(\mathrm{N}=306)$ so far, which they then analyzed, extracted key elements of the definition of terrorism and finally proposed their own definition. Modeling the aforementioned authors, and for the purposes of this paper, a qualitative and quantitative content analysis was used to detect the key elements of the term "intelligence".

Based on a qualitative content analysis of definitions of the term intelligence, key elements of each definition were extracted. The rows of the database contain definitions, while the columns contain the definitions' elements extracted through the content analysis. Initially, 24 elements were identified, but those terms that appeared in at least $10 \%$ of the definitions were retained. In this way, $15^{7}$ key elements of the concept of intelligence were detected. The constituent elements from 1 to 15 were then extracted into the database in columns for each definition, where the binary system figures $(0$ and 1) denote those elements that a specific definition contains or does not contain. After each definition was assigned with its constituent elements, a quantitative content analysis was performed to determine the frequency of the elements in the 35 base definitions. Finally, elements of the definitions were extracted, and then synthesized into a newly proposed definition of the term intelligence.

\section{Elements of the definition of intelligence}

Content analysis of the definitions of intelligence $(\mathrm{N}=35)$ extracted 15 items (Table 1). According to the results of the content analysis, the most represented element is "information" which appears in more than half of the definitions (65.7\%). This was followed by "end user/decision maker" (48.57\%), followed by "actionable character" (45.71\%), "foreign countries" (31.42\%), "knowledge" (28.57\%) and "national security" (28.57\%). 
Table 1: Results of quantitative and qualitative content analysis of definitions of the term "intelligence" ( $\mathrm{N}=35)$

\begin{tabular}{|l|l|l|l|}
\hline No. & \multicolumn{1}{|c|}{ Elements } & Frequency & \% \\
\hline $\mathbf{1 .}$ & Information & 23 & 65.71 \\
\hline $\mathbf{2 .}$ & End user/Decision maker & 17 & 48.57 \\
\hline $\mathbf{3 .}$ & Actionability feature & 16 & 45.71 \\
\hline $\mathbf{4 .}$ & Foreign countries & 11 & 31.42 \\
\hline $\mathbf{5 .}$ & Knowledge & 10 & 28.57 \\
\hline $\mathbf{6 .}$ & National security & 10 & 28.57 \\
\hline $\mathbf{7 .}$ & Collecting & 9 & 25.71 \\
\hline $\mathbf{8 .}$ & Request & 9 & 25.71 \\
\hline $\mathbf{9 .}$ & Dissemination & 7 & 20 \\
\hline $\mathbf{1 0 .}$ & Confidentiality & 7 & 14.28 \\
\hline $\mathbf{1 1 .}$ & Processing & 5 & 14.28 \\
\hline $\mathbf{1 2 .}$ & Enemy & 5 & 11.42 \\
\hline $\mathbf{1 3 .}$ & Analysis & 4 & 11.42 \\
\hline $\mathbf{1 4 .}$ & Threat & 4 & 11.42 \\
\hline $\mathbf{1 5 .}$ & Objectives & 4 & 20 \\
\hline & & & \\
\hline
\end{tabular}

If we compare the results of this analysis with other attempts to uniformly define the term and determine the key elements, it is clear that the survey of information as a basic element of the concept of intelligence correlates with the Wheaton and Beerbower's analysis /10/. They also estimated that information was an important element of the future definition. However, contrary to the findings of Warner, who considers that a key feature of intelligence is secrecy, this research did not establish the importance of this element, which coincides with the findings of the Wheaton and Beerbower investigations as well as that of Breakspear. Secrecy as a concept of data protection in terms of segmentation of the use and dissemination of intelligence products makes sense, for example to protect the conspiracy of the activity itself, while in the capacity of collecting raw data we consider secrecy a limiting factor, since in this sense it would mean that only classified information obtained from human sources had intelligence potential, which is certainly not the case.

In the subject analysis based on qualitative and quantitative content analysis, the element of secrecy only appears in $20 \%$ of definitions or 7 out of 35 . Hence, other authors of intelligence definitions do not consider secrecy to be an essential characteristic of the concept of intelligence. Prior to presenting the proposal of the definition itself, it is evident that in most of the definitions the importance of the actionable character is recognized, as this element also represents the whole purpose of intelligence as support to the end users' decision making process. If an intelligence institution is unable to present an intelligence product with an actionable character to end users, we cannot designate the product as an intelligence product. Knowledge is also highly represented element that clearly defines the term intelligence. The said outcome is logical since knowledge is made of information. Robert 
David Steele /37/ thus emphasizes that the basic source of national power is precisely information transformed into effective or useful knowledge, large portion of which is not classified.

The high representation of the "foreign country" element in this survey does not correspond with today's understanding of intelligence, so the relativization of the term to state activity directed toward foreign countries would be too selective. Therefore, the definition proposed in this paper is also flawed. Quite the opposite, intelligence, now more than ever, is not only a national characteristic, but the term is equally represented in other activities, more specifically in business, academia, sports, etc. However, this finding very likely stems from the fact that most of the definitions analyzed, 21 of them to be exact, were created before the 2000 s, and only four definitions emerged after 2010. It is plausible that four definitions from a period characterized by advances in information and communication technologies and the so-called "information boom", are not adequate for current contextualization and definition of the term intelligence. In addition, most definitions come from former securityintelligence personnel, government institutions, and the public that its expertise by engaging in the scientific community, which is probably the consequence of a narrow view on intelligence, gained from one point of view, that is, from the expert level.

Based on the five extracted elements (information, end user/decision maker, actionable character, foreign countries and knowledge), we have derived a new definition of the term intelligence. Intelligence is characterized by actionable knowledge of foreign/other countries that is disseminated in the form of information towards end users, i.e. decision makers.

The proposed definition is the result of a selective survey of intelligence corpus and view on intelligence. In this regard, future research should encompass a broader intelligence corpus and expand the database with more recent and numerous definitions, derived both by the expert and academic public. New research should use the scientific methodology, either quantitative and qualitative content analysis used in this paper or the Q-methodology mentioned earlier. Future research is essential in order to reconcile contentious definitional contents, not only to further develop intelligence theory and scientific discipline, but also to better understand this concept for a clearer use of intelligence in state activity.

\section{Conclusion}

The field of Intelligence Studies is characterized by a large number of different and often contradictory definitions of the term intelligence. In addition, Intelligence Studies as a field of knowledge is subordinate to other academic disciplines in the social sciences such as political science, history, sociology, psychology, and information and communication sciences $/ 6 /$, which further complicates defining the term uniformly. Second, each representative of the presented academic discipline looks at it from his or her specific paradigm. Furthermore, if experts employed by the intelligence system, who, unlike academics, undoubtedly possess essential empirical knowledge but with somewhat less theoretical knowledge, are included in the process of searching for a uniform definition, reaching a consensus will be additionally complicated. However, in order to define the term uniformly, it is important to include all Intelligence Studies stakeholders, both those who consider intelligence on the theoretical level and those who are involved in intelligence in practice. The creation of a large base of professional and academic definitions over which quantitative and qualitative analysis of extracted elements was conducted, as was the case in the this research, imposes itself as the most appropriate model for the study of defining intelligence uniformly. Until now, scientific and empirical knowledge has not focused on the unambiguous definition of the term, although this deficiency has often been referred to. One of the possible reasons for this is the lack of understanding of the term itself, as well as the traditions of individual states in conducting the activity. Nevertheless, some consider the term intelligence to be 
"incomprehensible" /3/, /9/ for Der Derian it is "misunderstood" /38/ within and outside of the intelligence community, making it difficult to define it uniformly; however, in the context of enhancing intelligence knowledge, it is certainly necessary to document all that is known so far $/ \mathbf{6} /$. Some other reasons for the fact that there is no uniform definition of the term intelligence should also be looked for. First of all, there are different types of intelligence, that is, the term is related to an intelligence product or information, the process/cycle of collecting, processing, analyzing and disseminating information, and an organization that produces intelligence knowledge. Furthermore, it is a broad concept, throughout history developed and presented initially as a state feature, to later become equally prevalent in business, sports, academic, scientific, and private discourse. Also, there are differences in the traditions of states and their understanding of intelligence, such as the intelligence model of the United States of America and the United Kingdom. Finally, there is a discrepancy between the opinions of the academic and expert communities, that is, between the theory and practical experience.

This paper presents the results of an empirical study of 35 available definitions of the term intelligence, and the extracted elements, that is, key elements according to the quantitative analysis of the content of overall occurrence, suggest that a minimum level of scientific consensus of the term intelligence has been reached. According to the results of the content analysis, the most represented element is information, which appears in more than half of the definitions (65.7\%). This is followed by the end user/decision maker (48.57\%), followed by the actionable character $(45.71 \%)$, foreign countries $(31.42 \%)$ and knowledge $(28.57 \%)$. Based on the five elements extracted, a new definition is presented.

Intelligence is characterized by actionable knowledge of foreign/ other countries that is disseminated in the form of information towards end users, i.e. decision makers.

Future research should necessarily be directed toward further gathering and analyzing existing intelligence knowledge, that is, updating the constructed database of intelligence definitions, with the aim of finding a common denominator and identifying the key elements that best define this complex but extremely important term. The importance of uniform defining of the term "intelligence" is crucial not only for the development of the academic discipline itself, but also for the practical part of "intelligence", which is an essential feature of every state as it provides support to state decision-making as well as defining national security policies.

\section{Notes}

/1/ Warner, M. (2002). Wanted: A Definition of Intelligence. Studies in Intelligence Vol. 46, No. 3, pp, 15-22.

/2/ Laquer, W. (1985). A World of Secrets: The Use and Limits od Intelligence (New York: Basic Books; 1985) in Troy, T. F. (1991) The "correct" definition of Intelligence. International Journal of Intelligence and Counterintelligence, Volume 5, 1991 - Issue 4, pp, 433-454.

/3/ Bimfort, M. T. (1958). A Definition of Intelligence, Studies in Intelligence, Volume 2, Issue Fall, Year 1958.

/4/ Kahn, D. (2002) in Scott, L., Jackson, P. (2004). The Study of Intelligence in Theory and Practice, Intelligence and National Security, 19: 2, pp,139169.

/5/ Warner, M. (2007). Sources and methods for the study of intelligence in Johnson, Loch K (2007) Handbook of Intelligence Studies, Routledge, pp, 17-27.

/6/ Marrin, S. (2014). Improving Intelligence Studies as an Academic Discipline, Intelligence \& National Security 31 (2), pp,1-14.

/7/ Bilandžić, M., Lucić, D. (2015). The plurality of meanings 'terrorism' - the theoretical and the practical importance of understanding the phenomena. Security Dialogues 6 (1), pp, 43-60.

/8/ Bilandžić, M. (2014). "The Seeds of Evil: An Introduction to the Studies of Terrorism", Despot Infinitus, Zagreb.

19/ Breakspear, A. (2013). A New Definition of Intelligence, Intelligence and National Security, 28: 5, pp, 678-693.

/10/ Wheaton, K. J., Beerbower, M. T. (2006). Towards a new definition of intelligence, vol. 17 Stanford Law \& Policy Review 319, Vol. 17:317, pp, 319-330.

/11/ Troy, T. F. (1991) The "correct" definition of Intelligence. International Journal of Intelligence and Counterintelligence, Volume 5, 1991 - Issue 4, pp, 433-454. 
/12/ Scott, L., Jackson, P. (2004). The Study of Intelligence in Theory and Practice, Intelligence and National Security, 19: 2, pp, 139-169.

/13/ Giles, L. (2000). "Sun Tzu On The Art Of War". Allandale Online Publishing.

/14/ Biblija (2019). "Stari i Novi zavjet: Knjiga Brojeva" Kršćanska sadašnjost, https://biblija.ks.hr/knjiga.aspx?g=4

/15/ Kent, S. (1949). "Strategic Intelligence for American World Policy". New Jersey. Princeton University Press.

/16/ Shulsky, A. N., (1991). "Silent Warfare". Understanding the world of intelligence. Brassey's (US), Inc.

/17/ Herman, M. (1997). “Intelligence power in peace and war". The Royal Institute of International Affairs, Cambridge University Press.

/18/ Kirkpatrick, B.L. (1997). "Intelligence", in: Jentelson, W.B. ; Patterson, G.T. (eds.) Encyclopedia of US Foreign Relations, Volume 2, New York: Oxford University Press.

/19/ Tuđman, M. (2002). Information science and intelligence. Informatologia, 35 (4), pp, 244-251.

/20/ Lowenthal, M.M. (2012). “Intelligence from Secret to Policy". Fifth Edition, Sage.

/21/ Javorovic, B., Bilandžić, M. (2007). "Business information and business intelligence". Golden Marketing - Technical Book, Zagreb.

/22/ Bay, S. (2007). "Intelligence theories A literary overview". Lund university. Research Policy Institute. Essay.

/23/ Marrin, S. (2007). Intelligence Analysis Theory: Explaining and Predicting Analytic Responsibilities. Intelligence and National Security, 22: 6, pp, 821846.

/24/ Johnson, L. K. (2008). Sketches for a theory of strategic intelligence in Gill, P., Marrin, S., Phythian, M. (2008). Intelligence Theory, Studies in intelligence series.

/25/ Phythian, M. (2008). Intelligence theory and theories of international relations: shared worlds or separate worlds? in Gill, P., Marrin, S., Phythian, M. (2008). Intelligence Theory, Studies in intelligence series.

/26/ Intelligence. Oxford Dictionary, https://en.oxforddictionaries.com/definition/intel ligence

/27/ Intelligence. Cambridge Dictionary, https://dictionary.cambridge.org/dictionary/eng1 ish/intelligence

/28/ CIA (1955). Commission Report on Intelligence Activities,

https://www.cia.gov/library/readingroom/docs/ CIA-RDP86B00269R000100020003-5.pdf

/29/ Bilandžić, M., Mikulić, I. (2007). Business intelligence and national security, Polemos 10 (2007) 1: pp, 27-43.

/30/ Godson, R. cited in Davies, P.H.J. (2009). Ideas of Intelligence: Divergent Concepts and National Institutions in Richard, J.A., Wark, W., Andrew, C. (2009). "Secret Intelligence: a reader". Routledge, London and New York.

/31/ Dedijer, S., Jequier, N. (1987). “Intelligence for Economic Development: An Inquiry into the Role of the Knowledge Industry". Oxford, Hamburg, New York: Berg.

/32/ Scott, L., Jackson, P. (2009). What is intelligence in Richard, J.A., Wark, W., Andrew, C. (2009). "Secret Intelligence: a reader". Routledge, London and New York.

/33/ Davies, P.H.J. (2009). Ideas of Intelligence: Divergent Concepts and National Institutions in Richard, J.A., Wark, W., Andrew, C. (2009). “Secret Intelligence: a reader". Routledge, London and New York.

/34/ DOD (2012). "Dictionary of Military and Associated Terms", https://www.jcs.mil/Portals/36/Documents/Doctr ine/pubs/dictionary.pdf

/35/ Diaz, M. (2011). Forming a Definitional Framework for Intelligence. American Intelligence Journal, Vol 29, No. 1, pp. 53-64.

136/ Schmid, A. P., Jongman, A. J. (1988). Political Terrorism: A New Guide to Actors, Authors, Concepts, Data Bases, Theories and Literature. Amsterdam: North-Holland Publishing Company.

/37/ Steele, R. (2006). Open Source Intelligence in Johnson, L.K. (2009). Handbook of Intelligence Studies. Routledge.

138/ Der Derian cited in Herman, M. (1997). "Intelligence power in peace and war". The Royal Institute of International Affairs, Cambridge University Press. 